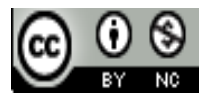

Jurnal Pendidikan Dasar Indonesia is licensed under

A Creative Commons Attribution-Non Commercial 4.0 International License

\title{
Student Profile Toword Course Activities At PGSD FKIP University Widya Dharma Klaten
}

\author{
Bayu Purbha Sakti, S.Or., M.Pd \\ Universitas Widya Dharma Klaten, Indonesia \\ E-mail : bayups@unwidha.ac.id
}

\begin{abstract}
bstract. The research was backgrounded by a decrease in the number of students who enrolled in Unwidha Klaten's PGSD Study Program. The study focused on the profile of students towards the PGSD FKIP Klaten Widya Dharma University lecture activities. Data collection uses an instrument in the form of a questionnaire. Processing data using editing, explanation information, diagrams, and percentage explanations. The research conclusions are explained as follows. The majority of Unwidha Klaten's PGSD students in 2017 have selfexplanations such as being born in Klaten before the millennium, having a productive age, having traits, and predominantly female characters. The majority of Unwidha Klaten's PGSD students in 2017 have family information such as having to struggle to get more information about bachelor diplomas, civil servants, private teachers, love their siblings, be an example, and a good example in the family. The majority of Unwidha Klaten's PGSD students in 2017 have health information such as being able to maintain their weight, height, eye health, hearing health, should not be considered arrogant because they do not have recurrence of disease and accident problems. The majority of Unwidha Klaten's PGSD students in 2017 have lecture information such as having the desire to become an elementary school teacher, taking a distance of more than 1 kilometer with up to 1 hour, choosing the subjects they like and the hardest courses, namely PGSD courses.
\end{abstract}

Keywords: Profile of students; PGSD lectures; PGSD Students

\section{INTRODUCTION}

The number of participants who passed the selection at 78 State Universities (PTN) in Indonesia were 101,906 students [1]. The number of prospective students is the result of a selection conducted by the Central Committee in Jakarta and accepted on the state campus. Therefore, these results affect the opportunities for prospective students to be accepted on private campuses. Prospective students accepted also affect the cost and income of a college.

Higher education has a role in the actions experienced by students [2]. The actions of students are also influenced in terms of tuition fees. Mohammad Nasir explained that not until students who have been accepted cannot enter because they cannot afford the tuition fees [3]. Public and private universities must be able to anticipate these tuition fees.

The high cost of education is felt 2 The Makassar State University (UNM) Student of the Faculty of Education (FIP) has threatened to be unable to continue his studies [4]. The university should indeed choose the tuition limit, which is the appropriate Single Tuition (UKT). There are 2 female students who experience expensive tuition fees, namely Agi Astuti and Nuraeni. Agi Astuti is a 2017 Elementary School Teacher Education (PGSD) student and Nuraeni is a student of the
2016 Education and Guidance (UN) Psychology Department. The amount of the Single Tuition (UKT) budgeted must match the economic background conditions of the two female students.

Azzumar Adhitia, a 2013 class student majoring in communication science, said the tuition fees were expensive, not comparable to what he got [5]. Azzumar complained about the cost of lectures on state campuses that are more expensive than private campuses. The decline in tuition fees that occur is not balanced with the provision of lecture facilities. One facility that needs to be repaired is class facilities such as a broken table. Other facilities that need to be improved are related to the procurement of books in the library.

Procurement of college books will support the implementation of lectures in universities. However, the implementation of lectures must also run according to the rules that apply such as the absence of compaction of time and courses. Region III Private Higher Education Coordination states that lecture activities held by private universities on Saturday-Sunday are illegal, because they are full of simplification and compaction courses [6]. Unfortunately, even though it has been banned, there are still many private universities that commit violations either by holding longdistance lectures or Saturday-Sunday lectures [7]. 
The lecture activities that have been undertaken do require online data that can be seen on the website of the Ministry of Research, Technology and Higher Education (Kemenristekdikti). Head of Sub Directorate of Information and Database Publication of Kemenristekdikti, Franova Herdiyanto explained that students will get a lot of losses if the data is not listed on the page forlap.ristekdikti.go.id [8]. Based on data from the forlap, public and private tertiary institutions need to be careful in entering data on students participating in lectures.

The 2011 students have not graduated but as many as 20 diplomas have been circulated and distributed while the diploma serial number does not connect with Higher Education university database (PDPT) because student data have not been reported to Dikti since the lecture took place in 2011 [9]. These are some of the problems experienced by a college. Data problem for every student who conducts lecture activities needs to be included at forlap.ristekdikti.go.id. Diploma numbering issues also need to be entered at pin.ristekdikti.go.id. therefore, the university must provide employees who serve these matters.

Marsaid is the Chancellor of the University of Sumatra, which has been established 12 years ago and has issued thousands of fake diplomas at a price of Rp. 10 million - Rp. 40 million without illegal permits [10]. Marsaid was raided by the Unit of Investigation and Criminal Unit (Satreskrim) Medan City Police Headquarters (Mapolresta) because it started from the large amount of information that came in related to the activities of unregistered campuses in the Region I Private Higher Education Coordination (Kopertis) Nangroe Aceh Darussalam (NAD) and Sumatra North (North Sumatra). The police investigated the fake diploma case by disguising themselves and pretending to buy an S-2 diploma without lecturing.

The process of lecturing activities is one aspect that needs to be assessed in the field of education. The lecture process carried out at the University of Widya Dharma Klaten requires student profile data. The student profile can be used as a reference to determine the eligibility of students to take lecture activities. The student profile can also be used to determine tuition fees.

Students are defined as individuals who study at the tertiary level, both public and private or other institutions at the same level as tertiary institutions [11]. Students must have a better profile compared to vocational or high school students in various fields. Educational information possessed by a student must be better than that of a student.

Students are categorized as people who have developmental stages of age 18 to 25 years [12]. Students have adult development and have a profile of creativity, initiative, proactivity, and energy in doing various things. Students have self and body development towards maturity. Information on the development of self and body possessed by a student must be improved by consuming nutritious food and drinks.

Students have a role and function as an iron stock in a nation's changing relay [13]. Students have an important role in organizing in the community and on campus even though students do not have to be activists. An important profile of students carried out on campus will be the capital for him to prepare for the country's development through his services. Students must prepare themselves to become respected figures who have a mental steel. Therefore the role of the family is needed. A family statement owned by a student will help the student profile to be more optimal in acting as a steel mental student.

Students have another important task as social control which is to observe and criticize what is happening in the community both on campus and outside campus and students are required to be sensitive to it [14]. Students are required to follow and understand the problems that occur in the community and campus. Students must have a solution to overcome problems that occur in society. The problems that occur must be resolved by controlling the public health psychologically and physically. Solid activity carried out by a student requires maintaining a health profile. Health information which is owned by a student must be processed by the student himself to avoid the ease of experiencing pain.

Students are referred to as intellectual candidates or in society are known as agents of change [15]. Students are intellectuals who have a much higher understanding of knowledge when compared to the level of education below. Students must bring a profile of change that is more advanced and better towards global developments. Students who have created inventions and have been successfully used by their nation have successfully become agents of change. This can be obtained by students from quality lecture activities and students must be earnest in learning it. The lecture information possessed by a student will help students as agents of change in information and other fields.

Elementary school teacher education courses have the privilege that students are prospective teachers who must have true teacher personalities. The responsibility of elementary school teachers is not only teaching but also educating and at the same time acting as a guide who gives direction and guides students in learning [16]. Elementary school students are expected to be positive-minded people and maintain peace [17]. Prospective teacher students must understand that they will produce the next generation of the nation which certainly has better quality than the current generation.

A teacher is said to be competent if he has mastered the four basic competencies [18]. Prospective teacher students must master professional, pedagogical, social, and personality competencies. Students who have mastered professional competence are required to be able to develop technology and research in the field of learning and curriculum. Students who have mastered pedagogical competence are required to be able to manage the preparation, processing, and evaluation of learning activities. Students who have mastered social competence are required to have good communication at the school, community, and national level. Students who have mastered personality competencies are required to be role models in various fields for their students later.

The character of students in higher education can be developed by lecturers through lecture activities based on soft 
skills [19]. Students are faced with writing papers and scientific works to develop intellectual potential and creativity in the future [20]. Lecture activities require a lecturer to become a role model for students. Lecture activities require students to be more independent in facing problems encountered in learning while lecturers only prepare lecture instructions.

The teacher has the right to determine and translate character education [21]. Lecture activities undertaken by the teacher education program must prepare students to become professional and qualified elementary school teacher candidates. Learning activities carried out in primary schools are closely related to planning, implementation, and outcomes [22]. Class activities must also show a picture of how elementary school teachers actually behave.

The development of teacher professionalism requires perseverance in the management system of the basic professional components needed for the preparation of teacher procurement through preservice education programs [23]. The program requires some development. Development of the ability to become a teacher and mastery of the material must be done. Teachers' teaching skills must also be developed. The program must also be complemented by prospective teacher education programs, personality formation programs, evaluation training programs, and field experience programs. To prepare professional teachers in the academic field, one of them is done with preconditions in the form of apprenticeship activities as an important part of preparing professional teachers [24]. Internships are activities undertaken by students so that students focus on managerial activities carried out at school. Students can develop teacher pedagogical abilities and modify learning tools.

\section{METHODS}

The approach used in this study is the survey research approach. Good survey design integral part of the usercentered experience (Geisen \& Bergstrom, 2017, p. 15). The purpose of the statement is that good survey design is an integral part of the experience that is centered or focused on the respondent.

Simple random samples work when every individual or thing in the population that is sampled can be identified (Cowles \& Nelson, 2015, p. 17). Simple randomized samples work when each individual or object in the population to be sampled can be identified. The samples taken in this study were all students of the Undergraduate Study Program in Elementary School Teacher Education and Education at the University of Widya Dharma Klaten 2017 class.

Data collection in this study was conducted using an instrument in the form of a questionnaire. The questionnaire used was an open questionnaire. When open ended survey questions are administered to the survey participant, the response is recorded verbatim or with extensive notes (Cowles $\&$ Nelson, 2015, p. 113). When open survey questions are given to survey participants, responses that are often recorded are word for word or with extensive notes. The research data was collected by giving open questions to students. The research instrument is compiled by writing an explanation of the personal information grid, family information, health information, education information, and lecture information.

\section{RESULT AND DISCUSSION}

The research conducted relates to the profile of students towards the lecture activities of the PGSD FKIP University of Widya Dharma Klaten producing research results which are the percentage of answers from the research instrument grid. The research instrument lattices written are personal information, family information, health information, education information, and lecture information. The answers derived from the questions compiled based on the research instrument's grid will be the subject of discussion. The results of the study on the profile of students towards the PGSD FKIP University Widya Dharma Klaten lecture activities will be discussed as follows:

\section{Self Description}

PGSD student Unwidha Klaten has self information in her birthplace. Birthplace information is distinguished in scope within Klaten Regency, Central Java Province, and outside Central Java Province. As many as 87.5 percent of total Unwidha Klaten PGSD students in 2017 class were born in Klaten Regency. As many as 12.5 percent of the total Unwidha Klaten PGSD students in 2017 class were born outside of Central Java Province. As many as 0 percent of total Unwidha Klaten PGSD students in the 2017 class were born in districts other than Klaten in Central Java Province. This shows that the majority of Unwidha Klaten PGSD students in the 2017 class were born in Klaten Regency. This also made the majority of Unwidha Klaten's PGSD students in the class of 2017 already familiar with Klaten Regency as their hometown.

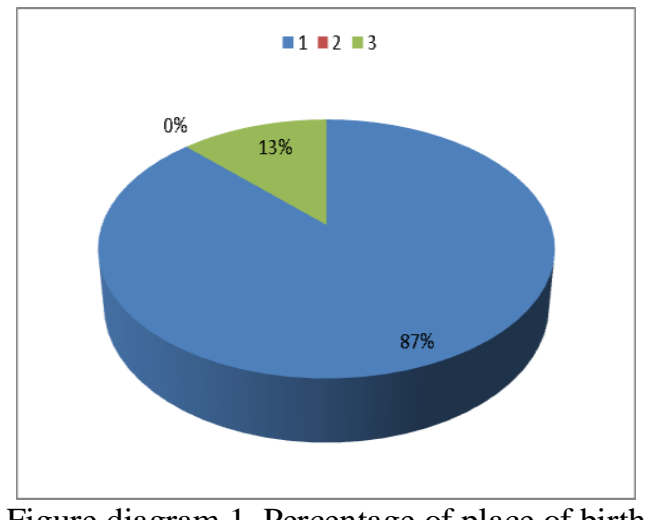

Figure diagram 1. Percentage of place of birth

PGSD students Unwidha Klaten has a personal statement on the date of her birth. Birth date information is distinguished in 2000, before 2000, and after 2000. A total of 87.5 percent of total Unwidha Klaten PGSD students in the 2017 class were born before 2000. As many as 12.5 percent of the total PGSD Unwidha Klaten 2017 students were born in 2000. A total of 0 percent of 
the total Unwidha Klaten PGSD students in class 2017 were born after 2000. This shows that most of the Unwidha Klaten PGSD students in 2017 were born before 2000. This also led to the majority of Unwidha Klaten's 2017 PGSD students being born before millennium era where there are changes that occur globally in all areas of life.

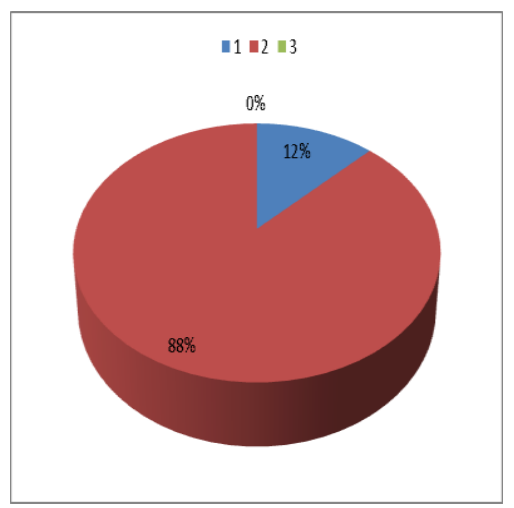

Figure diagram 2. Percentage of year of birth

PGSD students Unwidha Klaten has self-explanations in her gender. Sex description is distinguished in male and female sex. As many as 75 percent of the total 2017 PGSD Unwidha Klaten students have female gender. As many as 25 percent of the total Unwidha Klaten PGSD students in the 2017 class have male gender. This shows that most of the 2017 PGSD Unwidha Klaten students have female gender. This also led to the majority of Unwidha Klaten's PGSD students in the 2017 class having a predominantly female character and character.

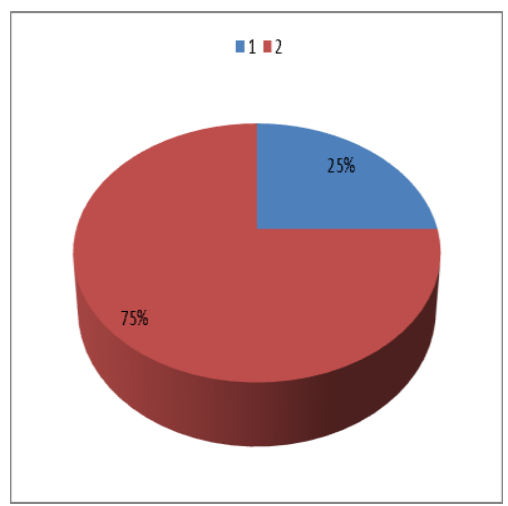

Figure diagram 3. Percentage of sex

PGSD students Unwidha Klaten has a personal description of her age. Information on age is distinguished by age 20 years, under 20 years, and over 20 years. As many as 71 percent of the total Unwidha Klaten PGSD students in 2017 have ages under 20 years. As many as 20.8 percent of the total 2017 PGSD Unwidha Klaten students have the age of 20 years. As many as 8.3 percent of the total Unwidha Klaten PGSD students in the 2017 class have ages above 20 years. This shows that the majority of Unwidha Klaten PGSD students in the 2017 class are under 20 years old. This also led to the majority of Unwidha Klaten PGSD students in the 2017 class having a productive age and having an early pregnancy risk for women.

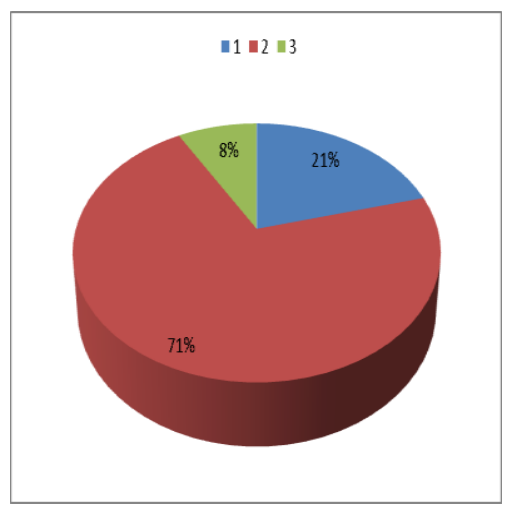

Figure diagram 4. Percentage of age

PGSD student Unwidha Klaten has information about herself in her residence. Residential information is distinguished in scope within Klaten Regency, Central Java Province, and outside Central Java Province. As many as 95.8 percent of the total 2017 Unwidha Klaten PGSD students reside in Klaten Regency. As many as 4.2 percent of the total 2017 Unwidha Klaten PGSD students live outside of Central Java Province. As many as 0 percent of the total 2017 Unwidha Klaten PGSD students live in districts other than Klaten in Central Java Province. This shows that the majority of Unwidha Klaten's 2017 PGSD students have a residence in Klaten Regency. This also causes the majority of Unwidha Klaten 2017 PGSD students to have easy access and transportation to Unwidha Klaten.

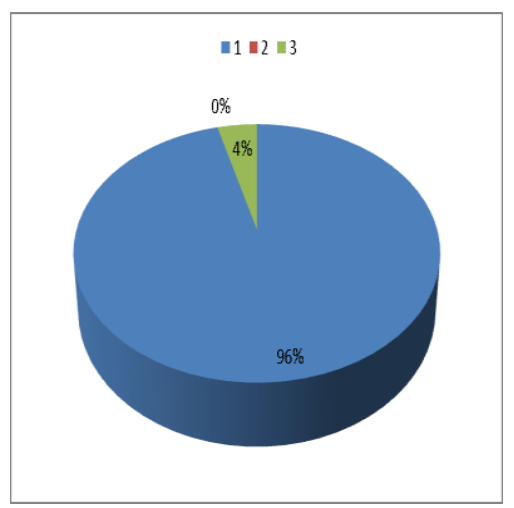

Figure diagram 5. Percentage of residence

2. Family Information

PGSD student Unwidha Klaten has information about her father's work in her family's statement. Description of father's work can be divided into 3 parts, namely the work of Civil Servants (PNS), private teachers, and other jobs. As many as 66.7 percent of the total Unwidha 
Klaten PGSD 2017 class students have fathers who work besides civil servants and private teachers. As many as 25 percent of the total PGSD Unwidha Klaten 2017 class students have fathers who work as civil servants. As much as 8.3 percent of the total PGSD Unwidha Klaten 2017 class students have fathers who work as private teachers. This shows that the majority of Unwidha Klaten 2017 PGSD students have fathers who work besides civil servants and private teachers. This also makes the majority of Unwidha Klaten 2017 PGSD students have to struggle to further deepen information about civil servants and private teachers.

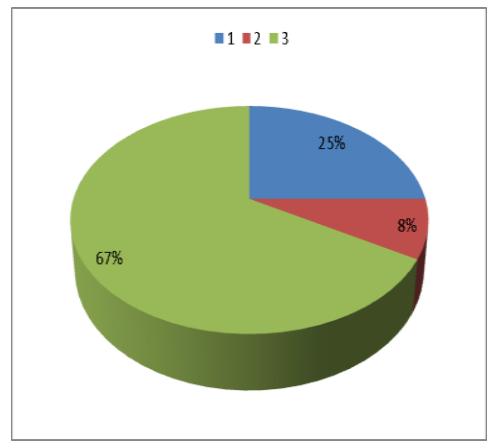

Figure diagram 6. Percentage of father's work

PGSD student Unwidha Klaten has a description of her father's diploma in his family's statement. Father's diploma information can be divided into 3 parts, namely diplomas for Civil Servants (PNS), bachelor, and diploma. As many as 62.5 percent of the total Unwidha Klaten PGSD 2017 class students have a father who has a certificate other than a bachelor's and diploma. As many as 38 percent of the total Unwidha Klaten PGSD students in 2017 have a father who has a bachelor's degree. As many as 0 percent of the total Unwidha Klaten PGSD students in 2017 have a father who has a diploma certificate. This shows that most of the Unwidha Klaten PGSD students in the 2017 class have a father who has a certificate other than bachelor and diploma. This also makes the majority of Unwidha Klaten's 2017 PGSD students have to try to get a bachelor's diploma as part of honoring their father's educational endeavors.

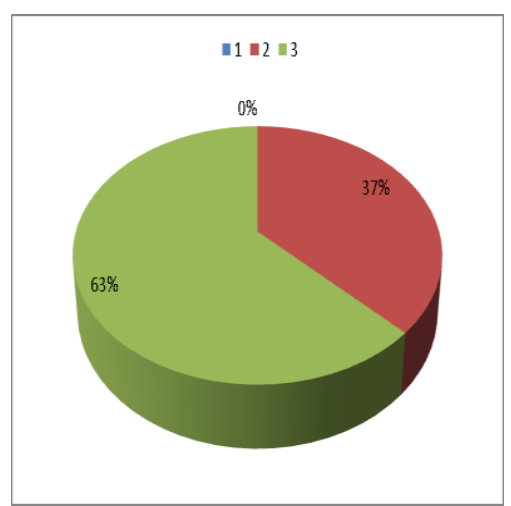

Figure diagram 7. Percentage of father's diploma
PGSD student Unwidha Klaten has information about her mother's work in her family's statement. Job description of the mother is divided into 3 parts, namely the work of Civil Servants (PNS), private teachers, and other jobs. As many as 7 percent of the total Unwidha Klaten PGSD 2017 class students have mothers who work besides civil servants and private teachers. As many as 25 percent of the total PGSD Unwidha Klaten 2017 class students have mothers who work as civil servants. As many as 8.3 percent of the total PGSD Unwidha Klaten 2017 class students have mothers who work as private teachers. This shows that the majority of Unwidha Klaten 2017 PGSD students have working mothers other than civil servants and private teachers. This also makes the majority of Unwidha Klaten 2017 PGSD students have to struggle to further deepen information about civil servants and private teachers.

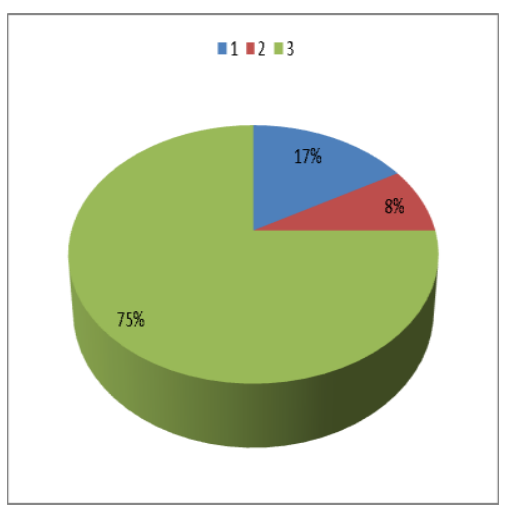

Figure diagram 8. Percentage of mother's work

PGSD student Unwidha Klaten has a description of her mother's diploma in her family's statement. The description of the mother's diploma can be divided into 3 parts, namely diplomas for Civil Servants (PNS), bachelor, and diploma. As many as 75 percent of total Unwidha Klaten PGSD 2017 class students have mothers who are certified other than undergraduate and diploma. As many as 17 percent of the total 2017 Unwidha Klaten PGSD students have mothers who have a bachelor's degree. As many as 8.3 percent of the total Unwidha Klaten PGSD students in 2017 have a diploma certificate. This shows that the majority of Unwidha Klaten 2017 PGSD students have mothers who have a diploma other than bachelor and diploma. This also makes the majority of Unwidha Klaten 2017 PGSD students have to strive to get a graduate diploma as part of respecting their mother's educational endeavors. 




Figure diagram 9. Percentage of mother's diploma

PGSD Students Unwidha Klaten has a description of the level as a child in her family's statement. Level information as a child is divided into 3 parts, namely the first, second, and more than two children. As many as 58 percent of the total PGSD Unwidha Klaten 2017 class students are the first children. As many as 25 percent of the total PGSD Unwidha Klaten 2017 class is the second child. As many as 16.7 percent of the total PGSD Unwidha Klaten 2017 class students are not the first or second child. This shows that the majority of Unwidha Klaten's 2017 PGSD students are the first children. This also makes the majority of Unwidha Klaten's 2017 PGSD students must be good examples and role models in the family.

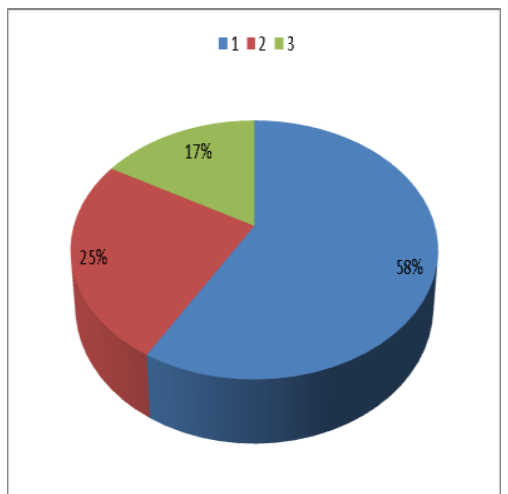

Figure diagram 10. Percentage of levels as a child

PGSD student Unwidha Klaten has a description of the number of siblings in her family's statement. Information on the number of siblings is divided into 3 parts, namely the number of siblings one, more than one, and no siblings. As many as 79.7 percent of the total PGSD Unwidha Klaten 2017 class students have more than one sibling. As many as 13 percent of the total PGSD Unwidha Klaten 2017 class students have one brother. As many as 8.3 percent of the total Unwidha Klaten PGSD 2017 class students have no siblings. This shows that the majority of Unwidha Klaten's 2017 PGSD students have more than one sibling. This also makes the majority of Unwidha Klaten's PGSD students in 2017 class have to love their siblings.

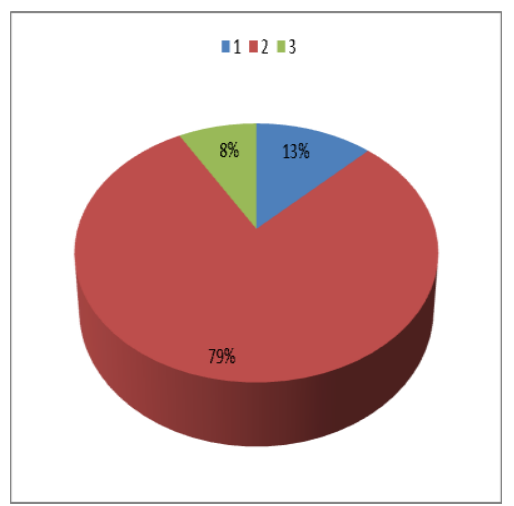

Figure diagram 11. Percentage of siblings

\section{Health Information}

PGSD student Unwidha Klaten has a height statement in her health statement. Description of height is divided into 3 parts, namely height less than 160, between 160 to 170 , and more than 170 centimeters. As many as 54.2 percent of the total PGSD Unwidha Klaten 2017 class has a height of between 160 and 170 centimeters. As many as 45.8 percent of the total PGSD Unwidha Klaten 2017 class has a height of less than 160 centimeters. As many as 0 percent of the total PGSD Unwidha Klaten 2017 class has a height of more than 170 centimeters. This shows that the majority of Unwidha Klaten's 2017 PGSD students have a height of between 160 and 170 centimeters. This also makes the majority of Unwidha Klaten PGSD students in the 2017 class should not consider arrogant with their height.

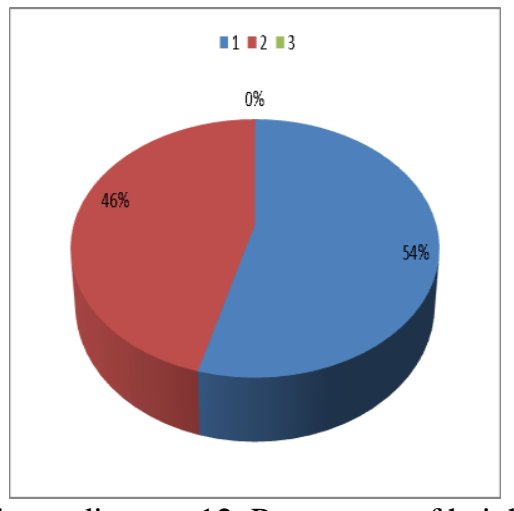

Figure diagram 12. Percentage of height

PGSD student Unwidha Klaten has a description of her weight in her health statement. Description of body weight is divided into 3 parts, namely weight less than 50 , between 50 to 60 , and more than 60 kilograms. As many as 46 percent of the total PGSD Unwidha Klaten 2017 class students weigh less than 50 kilograms. A total of 37.5 percent of the total PGSD Unwidha Klaten 2017 class students weigh between 50 and 60 kilograms. As 
many as 17 percent of the total PGSD Unwidha Klaten 2017 class students weigh more than 60 kilograms. This shows that the majority of Unwidha Klaten PGSD students in the 2017 class weigh less than 50 kilograms. This also makes the majority of Unwidha Klaten's 2017 PGSD students take care of their health by maintaining their weight.

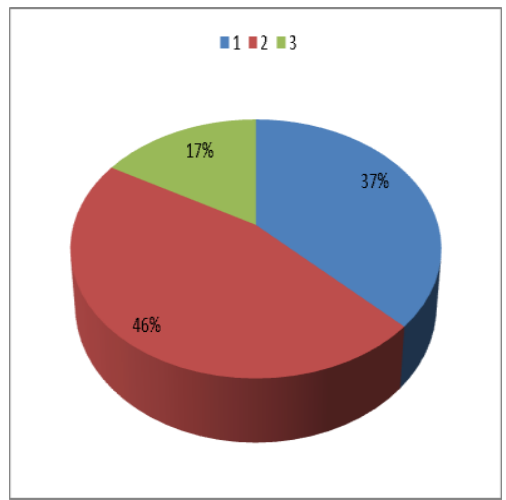

Figure diagram 13. Percentage of body weight

PGSD students Unwidha Klaten has a description of vision problems in her health statement. Description of vision problems can be divided into 2 parts, namely the presence and absence of vision problems. As many as 67.7 percent of the total PGSD Unwidha Klaten 2017 class students did not have vision problems. As many as 33.3 percent of the total PGSD Unwidha Klaten 2017 class students have vision problems. This shows that the majority of Unwidha Klaten's 2017 PGSD students do not have vision problems. This also makes the majority of Unwidha Klaten's PGSD students in 2017 class maintain their health by maintaining their healthy eyes.

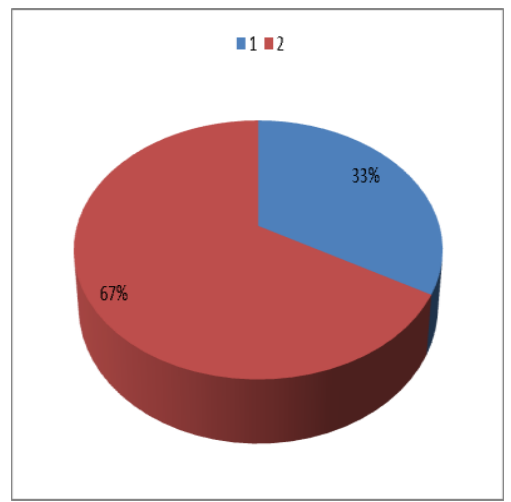

Figure diagram 14. Percentage of vision problems

PGSD Unwidha Klaten students have information on hearing problems in their health information. Description of hearing problems can be divided into 2 parts, namely the presence and absence of hearing problems. As many as 100 percent of the total PGSD Unwidha Klaten 2017 class students do not have hearing problems. As many as 0 percent of the total PGSD Unwidha Klaten 2017 class students have hearing problems. This shows that the majority of Unwidha Klaten's 2017 PGSD students do not have hearing problems. This also makes the majority of Unwidha Klaten's 2017 PGSD students take care of their health by maintaining their hearing health.

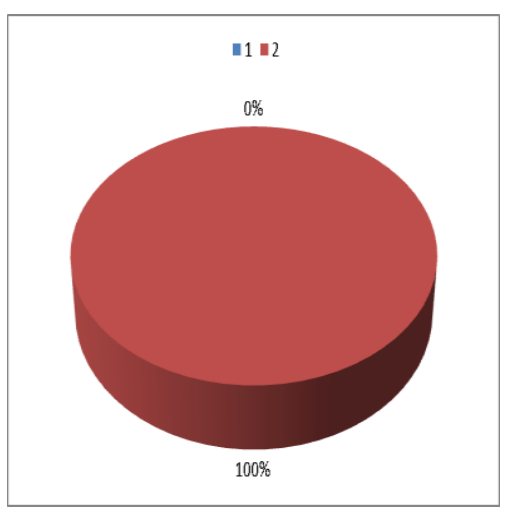

Figure diagram 15. Percentage of hearing problems

PGSD students Unwidha Klaten has information about relapse in her health statement. Description of recurrence is divided into 2 parts, namely the presence and absence of recurrence problems. As many as 87.5 percent of the total PGSD Unwidha Klaten 2017 class does not have recurrence problems. As many as 12.5 percent of the total Unwidha Klaten PGSD students in the 2017 class have recurrent disease problems. This shows that the majority of Unwidha Klaten PGSD students in 2017 do not have recurrence problems. This also makes the majority of Unwidha Klaten's PGSD students class 2017 so they don't become arrogant because they don't have a relapse.

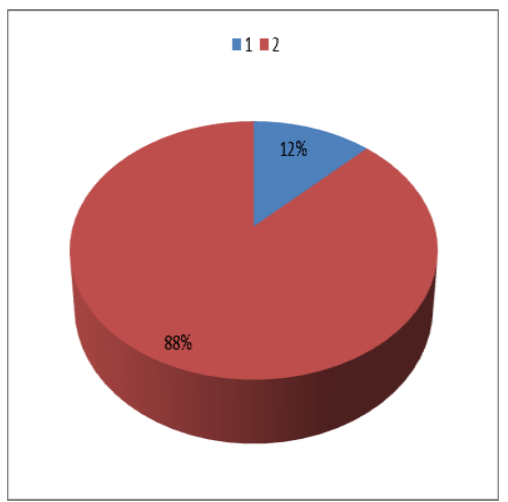

Figure diagram 16. Percentage of relapse

PGSD students Unwidha Klaten has information on accident issues in her health statement. Information on accident problems is divided into 2 parts, namely the presence and absence of accident problems. As much as 100 percent of the total PGSD Unwidha Klaten 2017 class students do not have accident problems. As many as 0 percent of total PGSD Unwidha Klaten 2017 class students have accident problems. This shows that the 
majority of Unwidha Klaten's 2017 PGSD students do not have accident problems. This also makes the majority of Unwidha Klaten's 2017 PGSD students aware of their travel activities to the campus so that there are no accidents.

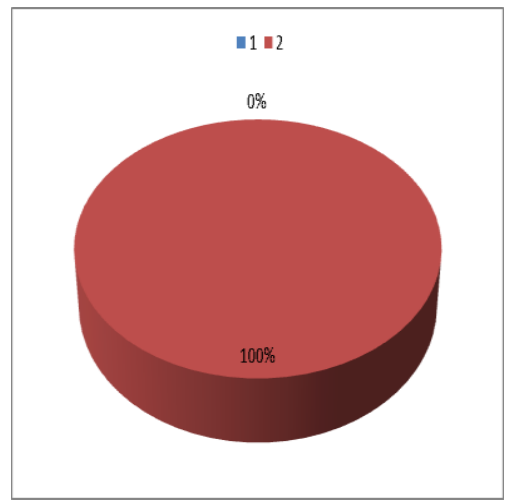

Figure diagram 17. Percentage of accident problems

\section{Information on Education}

PGSD Unwidha Klaten students have information on the types of elementary schools in their education information. Information on types of elementary schools is divided into 3 parts, namely types of public, private, and religious elementary schools. As many as 75 percent of the total 2017 PGSD Unwidha Klaten students are educated in public elementary schools. As many as 25 percent of the total 2017 Unwidha Klaten PGSD students are educated in religious elementary schools. As many as 0 percent of the total 2017 Unwidha Klaten PGSD students study in private elementary schools. This shows that the majority of Unwidha Klaten PGSD students in 2017 are educated in public elementary schools. This also makes the majority of Unwidha Klaten PGSD students in 2017 class elementary school graduates who are still purely implementing the government's education curriculum.

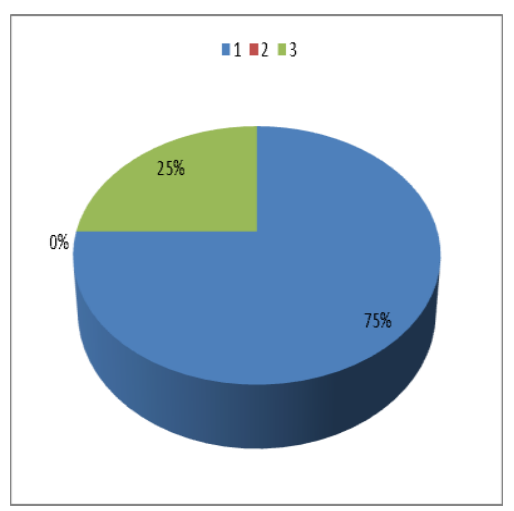

Figure diagram 18. Percentage of types of elementary school

PGSD Unwidha Klaten students have a description of the year of elementary school graduation in their education information. Information on graduating from elementary school is divided into 3 parts, namely graduating in 2011, before 2011, and after 2011. As many as 83.3 percent of the total 2017 Unwidha Klaten PGSD students have passed elementary school in 2011 A total of 16.7 percent of total Unwidha Klaten 2017 PGSD Students have passed elementary school before 2011. As many as 0 percent of the total 2017 Unwidha Klaten PGSD students have passed elementary school after 2011. This shows that most of the Unwidha Klaten 2017 PGSD students have passed elementary school in 2011.

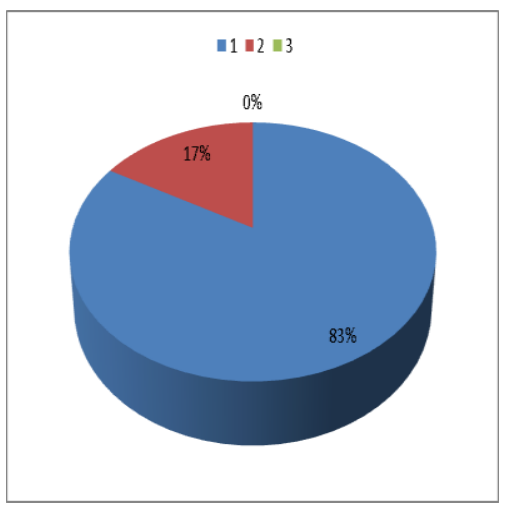

Figure diagram 19. Percentage of years graduating from elementary school

PGSD student Unwidha Klaten has a description of the type of junior high school in her education information. Information on the type of junior high school is divided into 3 parts, namely types of public, private, and religious junior high schools. As many as 83.3 percent of the total 2017 Unwidha Klaten PGSD students study in public junior high schools. As many as 16.7 percent of the total 2017 Unwidha Klaten PGSD students are educated in religious junior secondary schools. As many as 0 percent of the total 2017 Unwidha Klaten PGSD students are educated in private junior high schools. This shows that the majority of Unwidha Klaten's 2017 PGSD students are educated in public junior high schools. This also makes the majority of Unwidha Klaten's PGSD students in the 2017 class are junior high school graduates who are still purely implementing the government's education curriculum. 




Figure diagram 20. Percentage of type from junior high school

PGSD Unwidha Klaten students have a description of the year of junior high school graduation in their education information. Information on the year of junior high school graduation is divided into 3 parts, namely graduating in 2014, before 2014, and after 2014. As many as 83.3 percent of the total 2017 Unwidha Klaten PGSD students have passed junior high school in 2014. A total of 16.7 percent of total Unwidha Klaten 2017 PGSD students have passed junior high school before 2014. As many as 0 percent of the total 2017 Unwidha Klaten PGSD students have graduated from junior high school after 2014. This shows that most PGSD students in Unwidha Klaten class 2017 has graduated from junior high school in 2014.

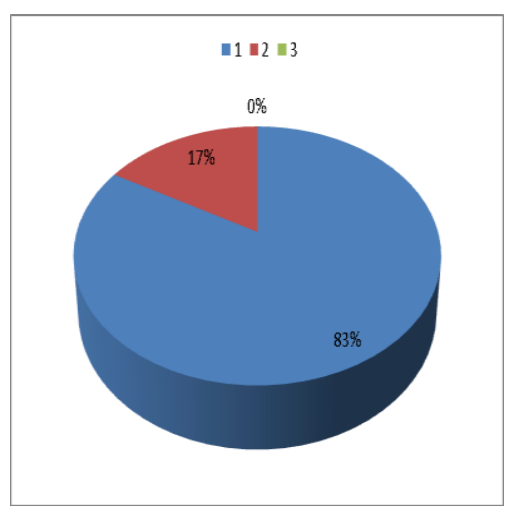

Figure diagram 21. Percentage of years graduating from junior high school

PGSD Unwidha Klaten students have information on the type of high school in their education information. The description of the type of high school is divided into 3 parts, namely the types of public, private, and religious high schools. As many as 75 percent of the total 2017 Unwidha Klaten PGSD students study in public high schools. As many as 16.7 percent of the total 2017 Unwidha Klaten PGSD students are educated in high school religion. As many as 8.3 percent of the total 2017 Unwidha Klaten PGSD students study in private high schools. This shows that the majority of Unwidha
Klaten's 2017 PGSD students study in public high schools. This also makes the majority of Unwidha Klaten's 2017 PGSD students high school graduates who are still purely implementing the government's education curriculum.

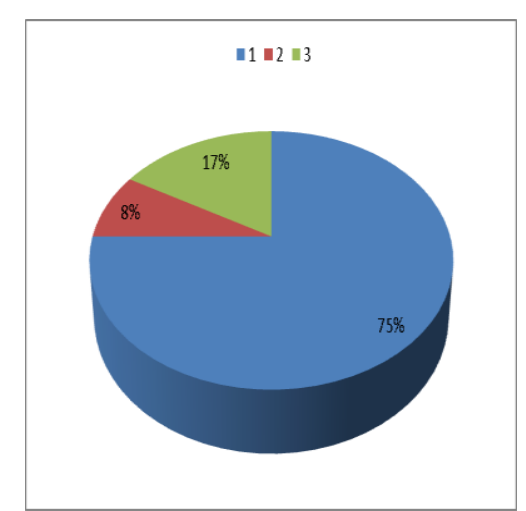

Figure diagram 22. Percentage of type from senior high school

PGSD Unwidha Klaten students have a description of the year of high school graduation in their education information. Information on high school graduation year is divided into 3 parts, namely graduating 2017, before 2017, and after 2017. As many as 83.3 percent of the total 2017 Unwidha Klaten PGSD students have passed high school in 2017. A total of 16.7 percent of the total 2017 Unwidha Klaten PGSD students have passed high school before 2017. As many as 0 percent of the total 2017 Unwidha Klaten PGSD students have graduated from high school after 2017. This shows that most PGSD students in Unwidha Klaten class 2017 has graduated from high school in 2017.

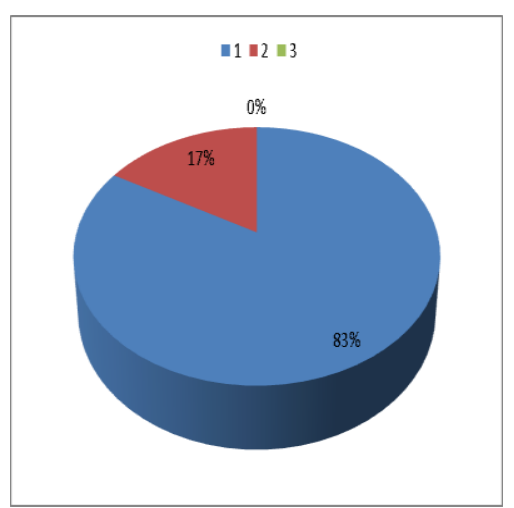

Figure diagram 23. Percentage of years graduating from senior high school

\section{Description of Lecture}

PGSD Unwidha Klaten students have information on the reasons for choosing Unwidha's PGSD in their lecture information. Information on the reasons for choosing Unwidha PGSD is divided into 3 parts, 
namely parents' expectations, their own desires, and other reasons. As many as 50 percent of the total 2017 Unwidha Klaten PGSD students choose the Unwidha PGSD department on their own terms. As many as 33.3 percent of the total 2017 PGSD Unwidha Klaten students chose the Unwidha PGSD department based on parents' expectations. As many as 16.7 percent of the total 2017 Unwidha Klaten PGSD students choose Unwidha PGSD majors based on other reasons. This shows that the majority of Unwidha Klaten's 2017 PGSD students choose Unwidha's PGSD department on their own terms. This also makes the majority of Unwidha Klaten's 2017 PGSD students want to become elementary school teachers with sincere intentions from themselves.

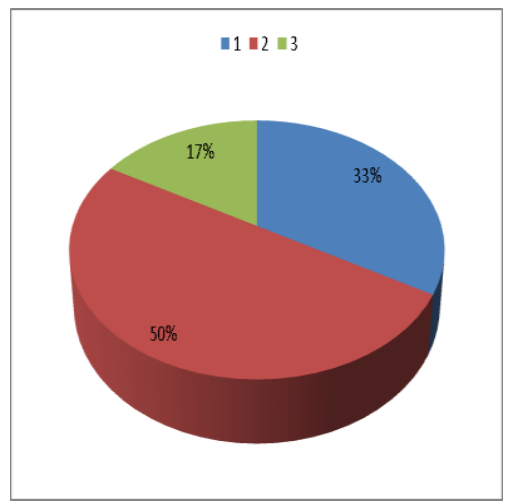

Figure diagram 24. Percentage of reasons for choosing Unwidha PGSD

PGSD Unwidha Klaten students have information on the reasons for choosing Widya Dharma University in their lecture information. Information on the reasons for choosing Widya Dharma University can be divided into 3 parts, namely the reason for having difficulty undergoing SNMPTN, the willingness of yourself, and other reasons. As many as 83.3 percent of the total PGSD Unwidha Klaten 2017 class students choose Widya Dharma University based on other reasons. As many as 16.7 percent of the total Unwidha Klaten PGSD students in the 2017 class choose Widya Dharma University based on the reasons for having difficulty undergoing SNMPTN. As many as 0 percent of the total PGSD Unwidha Klaten 2017 class students choose Widya Dharma University based on their own willingness. This shows that the majority of Unwidha Klaten's 2017 PGSD students choose Widya Dharma University based on different reasons.

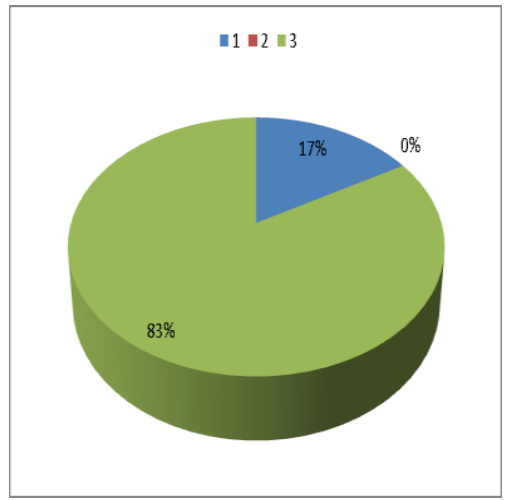

Figure diagram 25. Percentage of reasons for choosing Widya Dharma University

PGSD Unwidha Klaten students have information on choosing a favorite course in their lecture information. Information on choosing favorite subjects can be divided into 2 parts, namely choosing general subjects and elementary school education. As many as 71 percent of the total Unwidha Klaten PGSD 2017 class students choose their favorite courses are elementary school education courses. As many as 29 percent of total Unwidha Klaten PGSD students in the 2017 class choose their favorite courses are general courses. This shows that the majority of Unwidha Klaten's 2017 PGSD students choose a primary school education course as their preferred subject. This also makes the majority of Unwidha Klaten's 2017 PGSD students choose the subjects they like to be taught specifically in an elementary school teacher education study program.

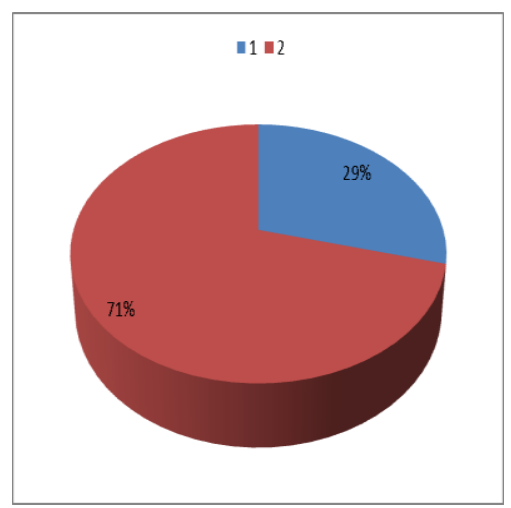

Figure diagram 26. Percentage of choice for favorite courses

PGSD Unwidha Klaten students have information on choosing the hardest course in their lecture information. Information on choosing the hardest courses is divided into two parts, namely choosing general subjects and elementary school education. As many as 79 percent of the total Unwidha Klaten PGSD students in the 2017 class choose the hardest courses, namely elementary school education. As many as 21 percent of the total Unwidha Klaten PGSD students in the 2017 class choose 
the hardest courses, namely general courses. This shows that most of the Unwidha Klaten 2017 PGSD students choose elementary school education courses as the most difficult subjects. This also makes the majority of Unwidha Klaten's 2017 PGSD students choose the hardest courses which are an important part of the courses taught to educate prospective elementary school teachers.

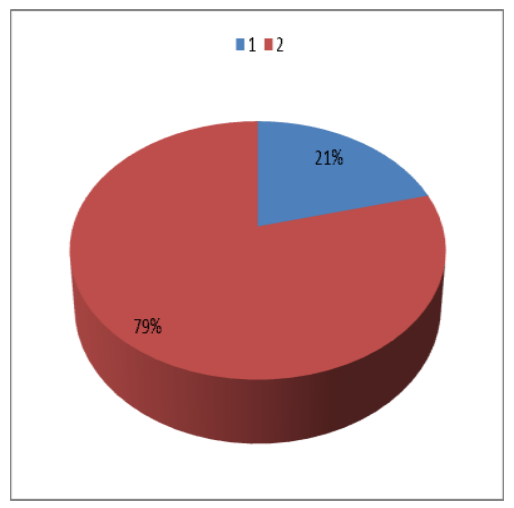

Figure diagram 27. Percentage of choices for the hardest courses

PGSD Unwidha Klaten students have information about the distance to the campus in their lecture information. Information on the distance to campus is divided into 2 parts, namely traveling up to 1 kilometer to campus and covering a distance of more than 1 kilometer to campus. As many as 83.3 percent of the total 2017 PGSD Unwidha Klaten students traveled more than 1 kilometer to campus. As many as 16.7 percent of the total 2017 Unwidha Klaten PGSD students travel up to 1 kilometer to campus. This shows that the majority of Unwidha Klaten's 2017 PGSD students traveled more than 1 kilometer to campus. This also made the majority of Unwidha Klaten's 2017 PGSD students go to college at Widya Dharma Klaten University with a distance of more than 1 kilometer.

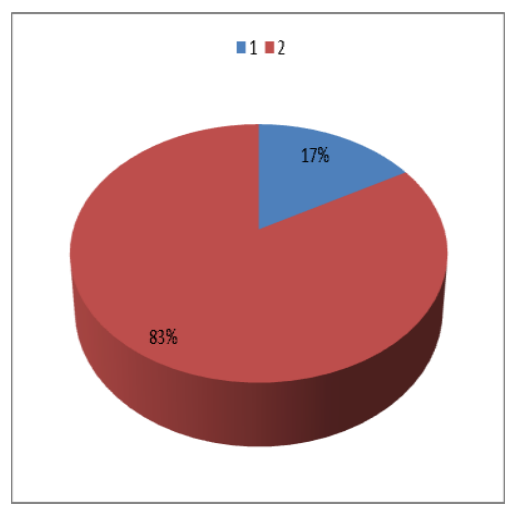

Figure diagram 28. Percentage of choice travels to campus

PGSD Unwidha Klaten students have information on campus time in their lecture information. Time to campus information is divided into 2 parts, which are up to 1 hour and more than 1 hour to campus. As many as 100 percent of the total 2017 Unwidha Klaten PGSD students take up to 1 hour to campus. As many as 0 percent of the total 2017 Unwidha Klaten PGSD students take more than 1 hour to campus. This shows that the majority of Unwidha Klaten 2017 PGSD students take up to 1 hour to campus. This also makes the majority of Unwidha Klaten's PGSD students in 2017 go to Widya Dharma University Klaten for up to 1 hour.

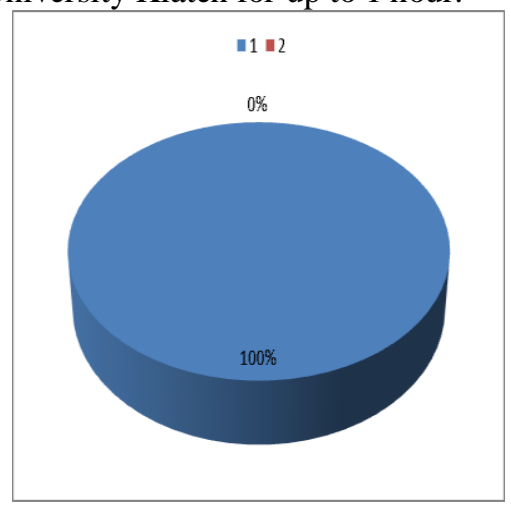

Figure diagram 29. Percentage of choice for time to campus

The students studied were sons and daughters who studied taking elementary school teacher education courses at Widya Dharma University, Klaten. The students are always enthusiastic in undergoing lecture activities. They are elementary school teacher candidates [27]. Although they sometimes find it difficult to understand the substance of lectures, there is always a maximum effort to solve them.

\section{CONCLUSIONS}

The conclusions obtained from the study of student profiles on the PGSD lectures at FKIP Widya Dharma University in Klaten are related to 5 information held by 2017 Unwidha Klaten PGSD students. The majority of Unwidha Klaten's 2017 PGSD students have self-explanations such as being born in Klaten before the millennium. productive age, have traits, and female-dominated characters. The majority of Unwidha Klaten's 2017 PGSD students have family information such as having to struggle to get more information about bachelor's diplomas, civil servants, private teachers, love their siblings, be an example, and a good example in the family. The majority of Unwidha Klaten's 2017 PGSD students have health information such as being able to maintain their weight, height, eye health, hearing health, should not be considered arrogant because they do not have recurrence of disease and accident problems. The majority of Unwidha Klaten's PGSD students in the 2017 class have lecture information such as having the desire to become an elementary school teacher, traveling more than 1 kilometer with up to 1 hour, choosing the subjects they like and the hardest courses, namely PGSD courses. 


\section{ACKNOWLEDGMENT}

The author would like to thank several parties who helped carry out research on the profile of PGSD students. Thank you to the Widya Dharma University Klaten and PGSD Study Program students.

\section{REFERENCES}

[1] Karsidi R, "Siaran Pers : Pengumuman Hasil SNMPTN 2017 Direktorat Jenderal Pembelajaran dan Kemahasiswaan,” 2017. [Online]. Available:

http://belmawa.ristekdikti.go.id/2017/04/26/siaran-perspengumuman-hasil-snmptn-2017/. [Accessed: 03-May-2018].

[2] B. P. Sakti, "Persepsi Mahasiswa Program Studi Pendidikan Guru Sekolah Dasar Universitas Widya Dharma Tentang Etika Mahasiswa," Prem. Educ. J. Pendidik. Dasar dan Pembelajaran, vol. 7, no. 02, p. 135, Dec. 2017.

[3] Khalifa S, "Kuliah Mahal di Universitas Negeri - Pikiran Merdeka," 2017. [Online]. Available: https://www.pikiranmerdeka.co/news/kuliah-mahal-universitasnegeri/. [Accessed: 03-May-2018].

[4] Songki G, "Mahalnya Biaya Kuliah! Solidaritas untuk 2 Mahasiswi FIP UNM | Berita Pilihan Terkini dan Terbaru Sulawesi Selatan,” 2018. [Online]. Available:

http://sulsel.pojoksatu.id/read/2018/01/26/mahalnya-biaya-kuliahsolidaritas-untuk-2-mahasiswi-fip-unm/. [Accessed: 03-May-2018]. Firman T, "Universitas Brawijaya: Banyak Peminat, Uang Kuliah Mahal - Tirto.ID,” 2017. [Online]. Available:

https://tirto.id/universitas-brawijaya-banyak-peminat-uang-kuliahmahal-cpiU. [Accessed: 03-May-2018].

[6] Wibisono K, "Kopertis nyatakan perkuliahan Sabtu-Minggu ilegal ANTARA News," 2014. [Online]. Available: https://www.antaranews.com/berita/444190/kopertis-nyatakanperkuliahan-sabtu-minggu-ilegal. [Accessed: 03-May-2018].

[7] Inung, "PTS Dilarang Selenggarakan Kuliah Jarak Jauh dan SabtuMinggu - Poskota News," 2014. [Online]. Available:

http://poskotanews.com/2014/03/17/pts-dilarang-selenggarakankuliah-jarak-jauh-dan-sabtu-minggu/. [Accessed: 03-May-2018].

[8] Puspita S, "Ini Kerugian jika Mahasiswa Tidak Terdaftar dalam PD Dikti - Kompas.com,” 2017. [Online]. Available: https://megapolitan.kompas.com/read/2017/07/11/15334011/ini.ker ugian.jika.mahasiswa.tidak.terdaftar.dalam.pd.dikti. [Accessed: 03May-2018].

[9] Woso R, "Mantan Puket 1 Tunliu Kasih Alasan Kenapa Ijasah Stikip Nusa Timor itu Ilegal - Halaman 3 - Pos Kupang,” 2018. [Online]. Available:

http://kupang.tribunnews.com/2017/09/14/mantan-puket-1-tunliukasih-alasan-kenapa-ijasah-stikip-nusa-timor-itu-ilegal? page $=3$. [Accessed: 03-May-2018].

[10] Leandha M, "Kampus Ilegal dan Jual Ijazah Palsu, Rektor Gadungan University of Sumatra Ditangkap - Kompas.com,” 2015. [Online]. Available:

https://regional.kompas.com/read/2015/05/28/1242029/Kampus.Ile gal.dan.Jual.Ijazah.Palsu.Rektor.Gadungan.University.of.Sumatra.D itangkap. [Accessed: 03-May-2018].

[11] Pambudi, "Hubungan Antara Tingkat Pengetahuan Kesehatan Reproduksi Dengan Respon Mahasiswa Terhadap Lgbt (Lesbian, Gay, Biseksual Dan Transgender)," Universitas Muhammadiyah Yogyakarta, 2017.

[12] K. Nurnaini, "Motivasi Berprestasi Mahasiswa Penyandang Tunadaksa," UIN Sunan Ampel Surabaya, 2014.

[13] R. Amri and G. Hendrastomo, "Dinamika Gerakan Kritis Mahasiswa Universitas Negeri," E-Societas, vol. 5, no. 1, pp. 1-11, Oct. 2016.

[14] I. S. Istichomaharani and S. S. Habibah, "Prosiding Seminar Nasional dan Call for Paper ke-2," 2016.

[15] R. Kurniawati and T. Leonardi, "Hubungan Antara Metakognisi dengan Prestasi Akademik pada Mahasiswa Fakultas Psikologi
Universitas Airlangga yang Aktif Berorganisasi di Organisasi Mahasiswa Tingkat Fakultas," J. Psikol. Pendidik. dan Perkemb., vol. 2, no. 1, 2013.

[16] B. P. Sakti, "Etika Dan Profesi Guru SD Di Tengah Perkembangan Zaman," Proceeding PGSD Univ. Kuningan 2016, vol. 1, no. 1, pp. 99-107, 2016.

[17] B. P. Sakti, "Feasibility Indicators Of Study Books Used Elementary School Students," in Social, Humanities, and Educational Studies (SHEs): Conference Series, 2018.

[18] A. Anugrahana, "Peningkatan Kompetensi Dasar Mahasiswa Calon Guru SD Pada Mata Kuliah Pendidikan Matematika Dengan Model Pembelajaran Inovatif," J. Penelit. (Edisi Khusus PGSD), pp. 182187,2016

[19] A. Aly, "Pengembangan Pembelajaran Karakter Berbasis Soft Skill Di Perguruan Tinggi," Ishraqi, vol. 1, no. 1, pp. 40-51, 2017.

[20] B. P. Sakti, "Training of Scientific Papers Writing On Students of Widya Dharma University," CARADDE J. Pengabdi. Kpd. Masy., 2018.

[21] B. P. Sakti, "Indikator Pengembangan Karakter Siswa Sekolah Dasar," Magistra Unwidha Klaten, vol. 30, p. 1, 2017.

[22] B. P. Sakti, "Indikator Sekolah Dasar Ramah Anak," Pros. Semin. Nas. PKO FKIP UTP, pp. 163-176, 2016.

[23] Mashuri, "Pengembangan Professional Keguruan Dalam Mata Kuliah Micro Teaching,” J. Ilm. Didakt., no. 1, pp. 80-97, 2012.

[24] B. Utami, "Pelaksanaan Magang Profesi Kependidikan Mahasiswa Pendidikan Kimia FKIP UNS," Surakarta, 2015.

[25] E. Geisen and J. R. Bergstrom, Usability Testing for Survey Research. Cambridge: Morgan Kaufmann, 2017.

[26] L. E. Cowles and E. Nelson, An Introduction to Survey Research. New York: Business expert, 2015.

[27] B. P. Sakti, "Training Writing Nonficial Stories In Students Of The PGSD Study Program Widya Dharma Klaten University," $J$. Berdaya Mandiri, vol. 1, no. 1, pp. 58-65, Aug. 2019. 